Sari Pediatri, Vol. 4, No. 3, Desember 2002: 152- 154

\title{
Telaah Kritis Makalah Prognosis
}

\author{
Bambang Tridjaja AAP
}

S

eringkali kita ditanya orang tua di tempat praktek seperti "Kalau anak saya tidak diobatildirawat, kemungkinan apa saja yang dapat terjadi pada anak saya?" Atau ketika berdiskusi dengan orang tua pasien diare yang telah diberikan cairan intravena, seringkali ditanyakan "Kira-kira tidak akan terjadi apa-apa kan dok, anak saya akan sembuh kan?" Pertanyaan pertama menggambarkan suatu skenario yang menyebabkan dokter harus menjelaskan kepada orang tua mengenai perjalanan alamiah penyakit. Pertanyaan kedua menggambarkan skenario suatu perjalanan klinis. Semua skenario tersebut mempunyai satu persamaan yakni menjelaskan mengenai prognosis.

Mengetahui prognosis suatu penyakit merupakan bagian dari pelayanan kesehatan yang kita berikan. Sudah kita ketahui bahwa prognosis seringkali menentukan pola pengobatan kita (pengobatan hipotiroid kongenital harus dilakukan sedini mungkin dan atau paling lambat sebelum usia 3 bulan untuk menghindari retardasi mental; sedangkan eritema toksikum neonatorum tidak membutuhkan pengobatan khusus), menentukan pemeriksaan penunjang yang dibutuhkan (pemeriksaan foto toraks pada pasien baru leukemia limfoblastik akut anak), dan follow up pasien (pemeriksaan darah tepi serial pada kasus demam berdarah dengue).

Apabila kita ingin mendapatkan informasi mengenai prognosis suatu penyakit, yang kita inginkan adalah suatu informasi yang terpercaya dan terkini. Untuk mendapatkannya sebaiknya kita membaca penelitian dari jurnal kedokteran. ${ }^{1-3}$ Namun seringkali kita dihadapkan pada kendala waktu, ketersediaan jurnal tersebut, dan pemahaman statistik. Pada uraian singkat ini akan dijelaskan langkah-langkah yang efektif

\footnotetext{
Alamat Korespondensi:

Dr. Bambang Tridjaja, M.MPed., Sp.A(K).

Staf Subbagian Endokrinologi. Bagian Ilmu Kesehatan Anak FKUI-RSCM. Jl. Salemba no. 6, Jakarta 10430.

Telepon: 021-3100669. Fax.: 021-390 7743.

email: b.parwoto@pacific.net.id
}

dan efisien untuk dapat menentukan apakah penelitian yang kita baca mampu memberikan informasi yang terpercaya dan terkini kepada orang tua tentang prognosis suatu penyakit yang diderita anaknya.

\section{Langkah-langkah EBM dalam Telaah Kritis Prognosis ${ }^{1,2}$}

Konsep Evidence Based Medicine (EBM) mengacu pada pelayanan kesehatan pasien sehingga langkah-langkah EBM selalu dimulai dengan mengetahui masalah apa yang ada pada pasien, dilanjutkan dengan menyusun pertanyaan klinis, baik mengenai masalah yang dihadapi pasien, mencari dan mendapatkan informasi yang dibutuhkan (apakah terpercaya dan berarti) untuk menjawab masalah tersebut, dan menilai apakah hasil penelitian dapat diterapkan kepada pasien. Terlihat bahwa satu siklus EBM dimulai dan diakhiri pada pasien.

Konsep EBM memberikan kata kunci untuk melakukan penelaahan kritis suatu penelitian secara efektif dan efisien adalah dengan menilai keabsahan (validity), arti penting hasil penelitian (importance), dan mampu tidaknya diterapkan pada pasien kita (applicability). Validity suatu penelitian dapat kita nilai dengan memperhatikan bab methode, importance kita lihat pada bab hasil, sedangkan applicability dapat kita lihat pada bagian discussion maupun methode.

Operasionalisasi V, I, dan A dilakukan dengan menjawab pertanyaan-pertanyaan yang telah disusun oleh tim EBM dari McMaster University dan sudah teruji selama 20 tahun.

\section{Validity}

Pertanyaan-pertanyaan untuk validitas merupakan perwujudan dari bentuk penelitian atau metodologi untuk mengetahui prognosis suatu penyakit. Sebagaimana kita ketahui untuk mengetahui prognosis suatu penyakit bentuk penelitian yang terbaik adalah bentuk kohor prospektif. Pertanyaan-pertanyaan 
mengenai validitas menggambarkan karakteristik suatu penelitian kohort.

Pertanyaan yang harus dijawab pembaca untuk menilai keabsahan penelitian adalah sebagai berikut,

1. Apakah sampel penelitian yang digunakan menggunakan kriteria inklusi dan eksklusi yang tegas dan merupakan sampel yang representatif?

2. Apakah pengamatan sampel dilakukan pada stadium penyakit yang sama (inception cohort)?

3. Apakah masa pengamatan sampel memadai dan tuntas?

4. Apakah outcome yang hendak diteliti dilakukan menggunakan kriteria yang objektif dan dilakukan secara "blind"?

5. Apabila terdapat sub sampel dengan prognosis yang berbeda-beda

a. Apakah dilakukan penyetaraan untuk faktorfaktor prognosis yang penting?

b. Apakah pada sub sampel tersebut dilakukan validasi?

Untuk menjawab pertanyaan pertama kita perhatikan kriteria inklusi dan eksklusi sampel dan apakah sampel representatif dengan populasi kasus yang kita hadapi di tempat kita bekerja. Penelitian yang dilakukan di rumah sakit rujukan bisa saja berbeda hasilnya dengan penelitian yang dilakukan di komunitas walaupun outcome yang diteliti sama. Hal ini disebabkan adanya referall filter bias. Ini terbukti dengan penelitian mengenai risiko kejang tanpa demam pada anak yang pernah menderita kejang demam. Penelitian di rumah sakit rujukan menghasilkan risiko yang jauh lebih besar dibandingkan dengan penelitian yang dilakukan secara community-based.

Pada studi kohort mengenai prognosis, kita mengamati perjalanan alamiah atau klinis satu penyakit pada sekelompok pasien sampai mencapai outcome yang kita ingin teliti (sembuh, lumpuh, retardasi mental, gagal ginjal, buta, meninggal, dan lain-lain). Oleh karena itu penting sekali untuk memulai pengamatan pada stadium yang sama dari penyakit tersebut dan atau dilakukan sedini mungkin. Sedini mungkin berarti pengamatan dilakukan pada perjalanan awal stadium penyakit yang hendak diteliti.

Waktu pengamatan terhadap sampel harus memadai sehingga mampu mendeteksi outcome yang diteliti. Apabila kurang maka mungkin saja outcome yang diteliti belum terjadi atau jumlah kasus dengan outcome tersebut terlalu sedikit sehingga sukar disimpulkan. Demikian pula kalau terlalu lama, kemungkinan terjadinya drop-out semakin besar. Disepakati bahwa apabila jumlah sampel pada akhir pengamatan $<80 \%$ dibandingkan awal pengamatan maka hasil penelitian tersebut tidak pantas untuk digunakan sebagai acuan. Apabila jumlah sampel pada akhir pengamatan $>95 \%$, hasil penelitian dapat dengan mantap digunakan sebagai acuan.

Tuntas pada pertanyaan kedua artinya pengamatan dilakukan sesuai dengan jadwal waktu yang ditetapkan atau dilakukan sampai mendapatkan outcome yang diinginkan.

Kriteria outcome yang diteliti harus mempunyai definisi operasional yang objektif (tertulis dan dapat diukur) tidak berdasarkan kemampuan diagnosis klinis semata. Demikian pula penilai outcome yang diteliti sangat diharapkan untuk tidak mengetahui ("blind") terhadap perjalanan klinis pasien, karakteristik maupun faktor-faktor prognosis sampel yang diteliti.

Apabila kita menjawab "ya" pada semua pertanyaan maka penelitian tersebut valid dan kita dapat melangkah lebih lanjut untuk menilai importance.

\section{Importance}

Untuk lebih memudahkan penjelasan mengenai makna prognosis suatu penyakit kepada pasien, biasanya kita menjelaskannya dalam bentuk kuantitatif. Misalnya dari suatu penelitian disimpulkan bahwa "bayi dengan berat badan lahir sangat rendah dengan riwayat ventrikulomegali akibat perdarahan intrakranial, mempunyai risiko untuk menderita kelainan neurologis sebesar $48 \%$ apabila bayi tersebut dapat hidup melewati usia satu tahun.” Kepada orang tua yang mempunyai bayi dengan karakteristik yang serupa dengan penelitian tersebut akan kita jelaskan sebagai berikut " Kemungkinan anak ibu untuk menderita gangguan neurologis setelah anak ibu berusia 1 tahun adalah mendekati 50\%”.

Agar kita mampu memberitahukan prognosis suatu penyakit, setelah mengetahui penelitian tersebut valid, maka kita jawab pertanyaan-pertanyaan sebagai berikut:

1. Berapa besarkah kemungkinan terjadinya outcome dikaitkan dengan rentang waktu tertentu?

2. Berapa besar ketepatan perkiraan prognosis tersebut?

Penelitian mengenai prognosis biasanya menggunakan proporsi sampel yang masih hidup pada saat tertentu (misalnya 5 year survival rate, median survival 
rate yaitu lamanya masa pengamatan hingga 50\% jumlah sampel telah meninggal atau survival curve yaitu menghitung proporsi sampel yang belum meninggal pada waktu-waktu yang telah ditetapkan)

Untuk lebih meyakinkan bahwa hasil penelitian bermakna, sebaiknya confidence interval dihitung. Semakin sempit confidence interval semakin bermakna hasil penelitian tersebut. Apabila hasil penghitungan confidence interval melampaui angka 1, maka penelitian sebaiknya ditinggalkan.

\section{Applicability}

Setelah kita yakin bahwa penelitian mengenai prognosis tersebuit valid dan penting, kita harus menjawab pertanyaan-pertanyaan di bawah ini untuk mengetahui apakah hasil penelitian dapat diterapkan di tempat kita bekerja, yaitu sebagai berikut,

- Apakah karakteristik sampel pada peneltian tersebut serupa dengan pasien di tempat praktek kita?

- Apakah hasil penelitian tersebut mempengaruhi keputusan kita terhadap apa yang perlu dilakukan atau perlu diberitahukan kepada pasien kita?

Karakteristik sampel penelitian dapat dilihat pada bab metoda. Selain memperhatikan karakteristik sampel perlu dilihat juga tempat penelitian berlangsung. Penelitian yang berlangsung di rumah sakit rujukan seperti RS Cipto Mangunkusumo atau RS Kanker Dharmais mungkin berbeda dengan karakteristik pasien yang berada di tempat kita bekerja. Dengan mengetahui prognosis penyakit, akan sangat membantu kita untuk menentukan apakah pasien kita perlu diberikan terapi atau tidak. Apabila kesimpulan kita mengatakan bahwa terapi tidak perlu diberikan, hasil penelitian tersebut tetap dapat dimanfaatkan kita untuk memberikan keterangan keterangan penting kepada penderita mengenai penyakit tersebut.

\section{Penutup}

Untuk para klinikus yang hendak melakukan telaah kritis, maka formulir daftar pertanyaan dapat diperoleh dari beberapa situs EBM yang ada. Sebagai contoh untuk prognosis dapat dilihat pada situs www.med.ualberta.ca/ ebm/prog.htm atau http://www.familypractice.ubc.ca/ research/binderevidence $18 . h \mathrm{tml}$

Untuk melengkapi kemampuan tatalaksana pasien, pengetahuan dan ketrampilan aspek prognosis pasien mempunyai peran penting. Tidak selamanya prognosis pasien sama seperti yang diajarkan pada saat kuliah mengingat berkembangnya ilmu pengetahuan, dan tidak semua prognosis penyakit kita ketahui. Membaca penelitian merupakan kegiatan yang seharusnya dilakukan dokter secara teratur, namun banyak kendala yang dihadapi.

Dengan melakukan pendekatan secara EBM, kita dimudahkan untuk membaca suatu hasil penelitian secara efektif dan efisien.

\section{Daftar Pustaka}

1. Sackett DL, Straus SE, Ricahrdson WS, Rosenberg W, Haynes RB. How to Practice and Teach EBM. Edisi kedua. Churchill Livingstone Edinburgh 2000.

2. How to read journals: III To learn the clincial course and prognosis of disease, Canadian Medical Association Journal 1981:369-72.

3. http://www.poems.msu.edu/InfoMastery/Prognosis/ Prognosis.htm.

4. Andreas Laupacis, George Wells, W. Scott Richardson, Peter Tugwell for the Evidence-Based Medicine Working Group. How to Use an Article about Prognosis. http:/ /www.cche.net/usersguides/prognosis.asp. 